九州大学学術情報リポジトリ

Kyushu University Institutional Repository

Flowering Habit and Fruit Setting of Pointed Gourd (Trichosanthes dioica Roxb.) Influenced by Seasonal Temperatures

HASSAN, Jahidul

Graduate School of Bioresource and Bioenvironmental Sciences, Kyushu University

MIYAJIMA, Ikuo

Institute of Tropical Agriculture, Kyushu University

https://doi.org/10.5109/2339051

出版情報: 九州大学大学院農学研究院紀要. 64 (2)，pp.177-182，2019-09-02. Faculty of Agriculture, Kyushu University

バージョン：

権利関係 : 


\title{
Flowering Habit and Fruit Setting of Pointed Gourd (Trichosanthes dioica Roxb.) Influenced by Seasonal Temperatures
}

\author{
Jahidul HASSAN ${ }^{1 *}$ and Ikuo MIYAJIMA ${ }^{2}$ \\ Institute of Tropical Agriculture, Kyushu University, \\ Fukuoka 819-0395, Japan \\ (Received April 17, 2019 and accepted May 8, 2019)
}

\begin{abstract}
Pointed gourd (Trichosanthes dioica Roxb.) is a dioecious cucurbit vegetable and fruit is the main edible part. In this experiment, we elucidated the flowering time temperature variations effect on the flowering habit, fruit yield and pollen germination ability under glasshouse and open field conditions. The highest number of female flowers (32.3), harvested fruits (29.6) and fruit weight (53.3 g) were found in 16-30 June with average day/night temperature $27.1 / 23.9^{\circ} \mathrm{C}$ in the glasshouse cultivation. Though, the number of female flowers were high (24.0) in 1-15 August $\left(30.8 / 27.5^{\circ} \mathrm{C}\right)$, but harvested fruits (13.6) and fruit weight (46.0 g) maximum in $1-15$ July $\left(29.1 / 26.7^{\circ} \mathrm{C}\right)$ and $16-30$ June $\left(25.2 / 22.2^{\circ} \mathrm{C}\right)$ in open field condition. On the other hand, the highest number of male flowers was produced in the glasshouse (51.6) and open field (35.0) during 16-31 July with different temperatures $\left(34.2 / 29.9^{\circ} \mathrm{C}\right.$ in glasshouse) and $\left(31.6 / 27.9^{\circ} \mathrm{C}\right.$ in open field). Results demonstrated that flowering habit of pointed gourd differed to a greater extent at high temperature than low temperature. Female flowering was accelerated up to a certain level of temperature $\left(27-30^{\circ} \mathrm{C}\right)$ and after that decreased, whereas, higher temperature (more than $30^{\circ} \mathrm{C}$ ) among the flowering time temperatures was found as favorable to increase male flowering regardless of growing conditions. Pollen germination rates were adversely affected due to high temperature and declined the fruit set rate and fruit yield in both growing conditions.
\end{abstract}

Key words: flowering habit, pointed gourd, pollen germination, Trichosanthes dioica, yield

\section{INTRODUCTION}

Pointed gourd (Trichosanthes dioica Roxb.) is dioecious cucurbit vegetable that originated in India and Bangladesh as tropical and subtropical regions (Kumar and Singh, 2012). Young green fruit which is 10-12 cm length (30-50 g) at 15-18 days after pollination is the main edible size and consumed as vegetable after cooking (Koley et al., 2009). It is widely cultivated in the summer and rainy season in Bangladesh from February to October and average temperature during this growing season is $30-33^{\circ} \mathrm{C}$ (BCDP, 2015). Due to its dioecism, cross pollination is inevitable for yield improvement that depends on early or delayed flowering, asynchrony between male and female flower development and reproductive maturity.

Floral induction and differentiation directly affect plant yield by determining the time of flowering, the number of flowers and fruits produced (Terefe and Tatlioglu, 2005). Cucurbit plants are cultivated for fruits and their fruit set is continuous, so flower sex determination, pollination, the total number of male and female flowers have a close relationship with the yield (Song et al., 2012). Although, the flower sex expression of cucurbits is mainly controlled by genes, it can also be influenced by plant hormones and environmental conditions (Yamasaki et al., 2005). The influence of environmental conditions on whether a male or female flower is formed

\footnotetext{
Graduate School of Bioresource and Bioenvironmental Sciences, Kyushu University, Fukuoka 819-0395, Japan

Institute of Tropical Agriculture, Kyushu University, Fukuoka 819-0395, Japan

* Corresponding author (E-mail: jhdalim@gmail.com)
}

has been extensively documented in cucumbers (Cantliffe, 1981). It has been claimed that moderate temperature and high light intensity favored development of female flowers in cucumbers while high temperature combined with low light conditions, reduced female flower numbers (Cantliffe, 1981). Unlike temperature, photoperiod is considered as the most influential factor on flowering in plants that are sensitive to day length (Wang, 2007). In dioecious species, individual of both sexes had produced different sex ratios at varying day lengths and temperatures in distinctive locations (Frick and Cavers, 1989; Taylor, 1994). Furthermore, the pollen per anther, its maturation, viability and fertility have been reported to negatively affected by seasonal temperature fluctuation, which have a direct impact on fruit quality and yield (Allan, 1963; Young et al., 2004).

Peter et al. (1998) suggested that pointed gourd (Trichosanthes dioica Roxb.) is a day neutral plant and $30-35^{\circ} \mathrm{C}$ temperature is optimum for its vegetative growth. But the scientific information regarding environmental factors that promote the occurrence of male and female flowering, flower physiology in pointed gourd are still very limited. Meanwhile, in our previous study, pointed gourd appears suited for cultivation in northern Kyushu of Japan as temperate climate (data not published). Now, it is necessary to find out the optimum growing time in context to the weather condition for producing this crop locally at farmers level. Therefore, the present study was carried out to examine the effect of growing season temperatures on flowering of both sexes and fruit setting of female pointed gourd in glasshouse and open field trials. 


\section{MATERIALS AND METHODS}

\section{Plant materials}

The mature vines of one female (PGF17) and male (PGM03) genotype of pointed gourd were planted in the plastic tray for regeneration in November 2016. The three sprouted vines of each genotype were transplanted to three plastic pots $(30 \mathrm{~cm}$ diameter) in the glasshouse and experimental open field of Kyushu University, Hakozaki campus (lat. $33^{\circ} 37^{\prime} \mathrm{N}$; long. $130^{\circ} 25^{\prime}$ E), Japan at a spacing of $2 \times 1 \mathrm{~m}$. Individual plant of these accessions (female and male) was considered as one replication and there were three replications.

\section{Flowering season temperature}

Air temperature in the glasshouse and open field was recorded precisely at $10 \mathrm{~min}$ intervals over the whole flowering season (from May 1, 2017 to October 30, 2017) using a Thermo recorder (TR-52, T\&D corporation, Japan). Afterwards, the average maximum, mean and minimum day and night temperatures of 15 days intervals of a month were calculated. Day length (h) data described in this study was obtained from the sunrise and sunset times in Fukuokashi online website (https://sunsetsunrisetime.com).

\section{Data analysis}

Due to the dioecious nature of pointed gourd, average male and female flower initiation was separately scored at 15 days intervals of a month from the first day of initiation to the end of flower production. Mature fruits at edible stage (18 days after anthesis) were counted, fruit length, diameter, number of seeds per fruit, fruit weight was also recorded. The fruit harvesting date was tagged according to the respective flowering date in order to analyze the effect of temperature on fruit set rate. All the recorded data were analyzed using R-software.

\section{Pollen germination test}

Pollen grains of fresh full blossomed flower in the glasshouse were collected at 2nd and 4th week of each month from May to October 2017 and cultured in in vitro germination media containing 5\% sucrose and $0.5 \%$ agar. With a flat blade or needle, the pollen was scraped onto smooth paper that was inclined and tapped to remove anthers and debris, leaving relatively pure pollen. The pollen was distributed on medium dispensed in $90 \mathrm{~mm}$ diameter petri dishes. Covered the petri dishes with its lids and the edge of these lids were wrapped with para-film paper to ensure uniform and high relative humidity in inside the petri dishes. The covered petri dishes were incubated at $25^{\circ} \mathrm{C}$ under dark conditions for $24 \mathrm{~h}$. Afterwards, observation slides were prepared by placing a small portion of germinating media with pollen grains on it and a cover slip was placed over the samples. The slides were then studied under a stereomicroscope (Leica DM2500, Olympus DP70 model) at 10x magnifications. A pollen grain was accepted as germinated when pollen tube length was at least equal to or greater than the pollen grain diameter (Leus, 2005). The germination of 100 pollen grains was counted in each microscopic observation field and it was done for 3 different optical fields in each slide. The mean value of 3 observations was calculated and considered to be the germination rate. In total, the germinability of 300 pollen grains per treatment was assessed.

\section{RESULTS}

The highest mean day and night temperature was $34.2 / 29.9^{\circ} \mathrm{C}$ in $16-31$ July and the lowest was $21.7 / 19.7^{\circ} \mathrm{C}$ in 16-31 October in the glasshouse (Fig. 1A). However, in open field (Fig. 1B), it was notice in 16-31 July $\left(31.6 / 27.9^{\circ} \mathrm{C}\right)$ and $16-31$ October $\left(21.0 / 17.9^{\circ} \mathrm{C}\right)$, which was on an average $2-3^{\circ} \mathrm{C}$ lower than those of glasshouse. On the other hand, the average day length 11-14 h was found in all the flowering season (Fig. 2).

In the glasshouse (Fig. 3A), flowering male and female flowers started from first week of May and gradually increased until 30 June for female and 32.3 flowers were recorded, whereas male flower increases until 31 July and 51.6 flowers were recorded. Afterwards, female flowering was progressively slowed down until at the end of August then rose to 24.3 flowers in 1-15 September and again gradually declined to the lowest in 16-31 October (3.3 flowers). Meanwhile, male flowering was gradually decreased form August and reached to the lowest in 16-31 October (1.3 flowers). Male genotypes seemed to have higher number of flowering than females from June to August, although lower flowering was observed in May, September and October.

In the open field, flowering in female and male genotypes was started at 1.5 months later of glasshouse during 16-30 June and finished 1 month earlier than glasshouse in 16-30 September (Fig. 3B). Female and male flowering was found as maximum in 1-15 August (24.0 flowers) and 16-31 July (35.0 flowers) respectively.

In the glasshouse, there was not much difference observed from 16-31 May to 1-15 July and 16-30 September in relation to fruit set rate, where more than 90\% fruit sets were recorded (Fig. 4A). Although, the best result was obtained in 16-30 June and the lowest was in 1-15 August considering the number of fruits obtained (Table 1). Besides, the smaller fruits with lower fruit length and diameter was produced from 16-31 July to 16-31 August whereas larger fruits with considerable length and diameter was found from 1-15 May to 1-15 June and 1-15 September to 16-30 October growing periods (Table 1 ). The fruit weight was higher in June (50.0-53.3 g) and decreased to the lowest (30.0$34.0 \mathrm{~g}$ ) in August (Fig. 4B). Fruits with maximum length $(13.0 \mathrm{~cm})$ and diameter $(3.5 \mathrm{~cm})$ have many seeds 31.6 when pollinated in 16-30 June compared to fruits of minimum length $(8.9 \mathrm{~cm})$ and diameter $(2.6 \mathrm{~cm})$ with few seeds (17.6) when pollinated in 1-15 August (Table 1).

On the other hand, flowers pollinated in 16-30 June, 


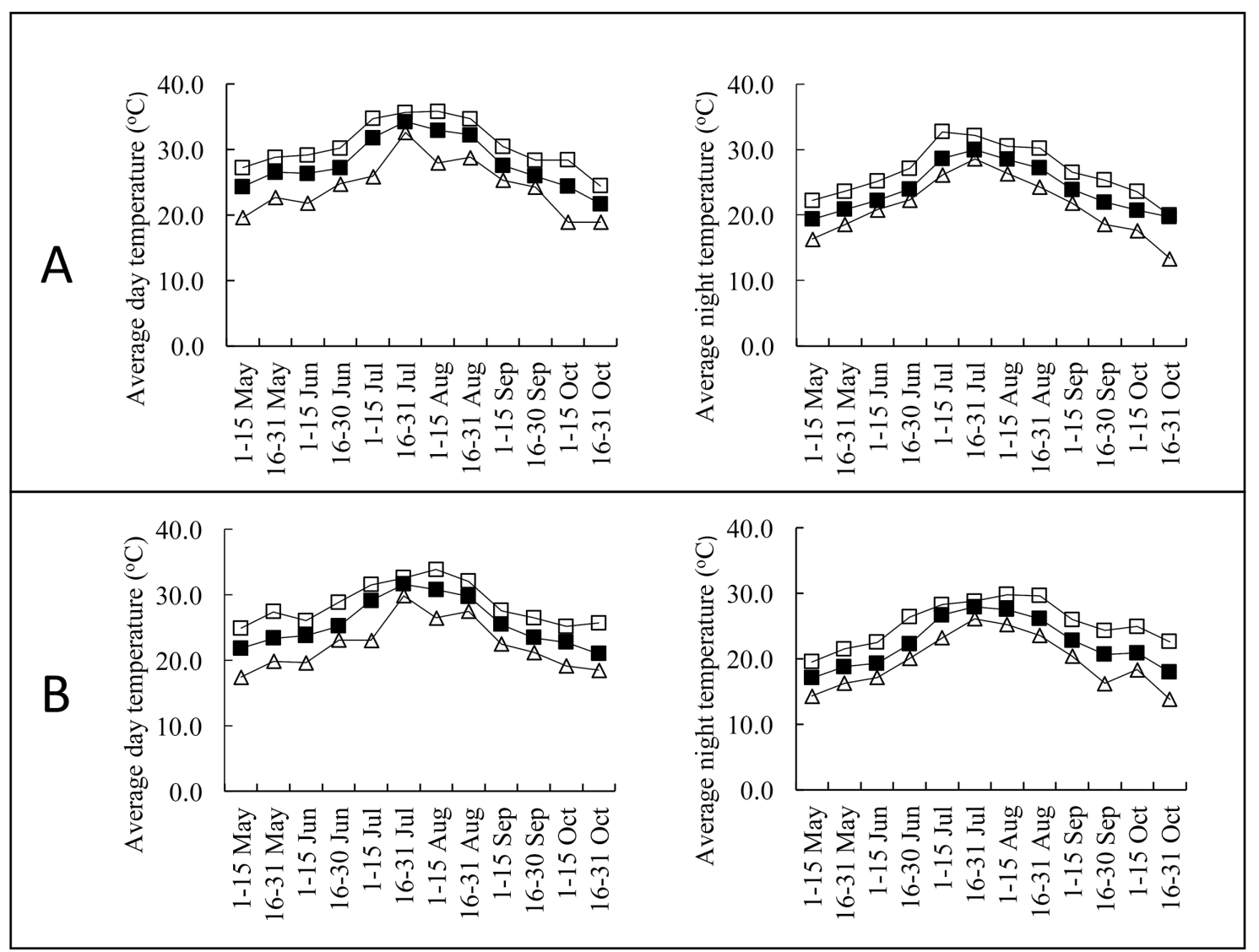

Fig. 1. The average maximum $(\square)$, mean $(\square)$, and minimum $(\triangle)$ day and night temperatures in the (A) glasshouse and (B) open field. Temperature data were recorded from May to October 2017.

1-15 July and 1-15 September produced the maximum fruit set rate, fruit weight with better fruit length, diameter and seeds than that of fruits produced in 1-31 August in open field (Fig. 4A; 4B; Table 1).

The pollen germination rate was high (79.3-93.3\%) in the flowers opened during $1^{\text {st }}$ May to 15 July (24.3$31.7^{\circ} \mathrm{C}$ ) and 1 st September to 31 October $\left(21.7-27.5^{\circ} \mathrm{C}\right.$ ) when the average temperature was more than $20^{\circ} \mathrm{C}$. Meanwhile, low pollen germination (24.7-48.67\%) was found in the flowers produced during 16 July to 31 August $\left(32.2-34.2^{\circ} \mathrm{C}\right.$ ) (Fig. 5) when the minimum temperature rose to more than $30^{\circ} \mathrm{C}$.

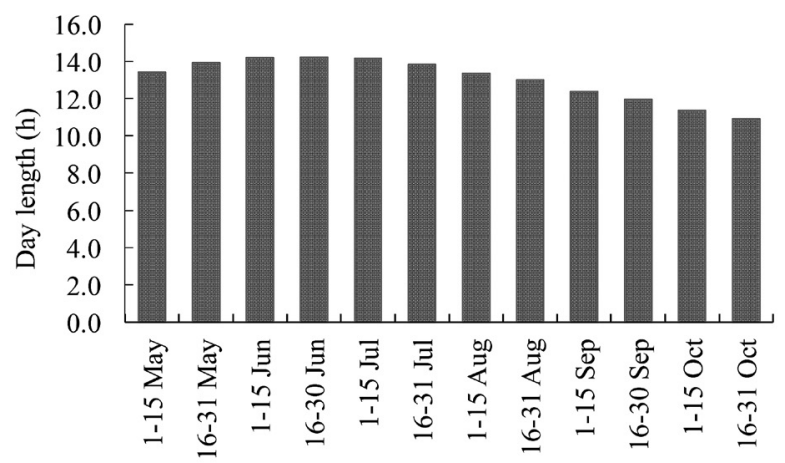

Fig. 2. Day length of flowering season of pointed gourd in 2017.

\section{DISCUSSION}

The results demonstrated that day length has no effect on the flowering habit of pointed gourd. Because, the average day length from May to October was 11-14 (h). Female and male flowering was done for the whole studied periods in glasshouse, while in the open field, no flower was observed from May to mid-June and October, although the day length was same for both the growing conditions. This finding agreed with the observation of Peter et al. (1998).

Flowering habit of male and female plants, responded differently to temperature when they were grown in glasshouse and open field. Male plants had mostly similar consistent flowering patterns in both growing habitats. It started flowering from the lowest rate and reached to the highest in a specific time when the temperature was high and gradually decreased with the reduction of temperature in the prolong growing periods. Besides, females had different flowering patterns where the number of female flowers were maximum at $27-30^{\circ} \mathrm{C}$ day temperature and minimum at below or above this temperature. These findings demonstrated that at high temperature, female flowering was low compared to male flower within the same day length in both growing habitats. This result substantiated with the previous findings of Rudich and Peles (1976) where they postulated that $27^{\circ} \mathrm{C}$ day temperature increased the ten- 

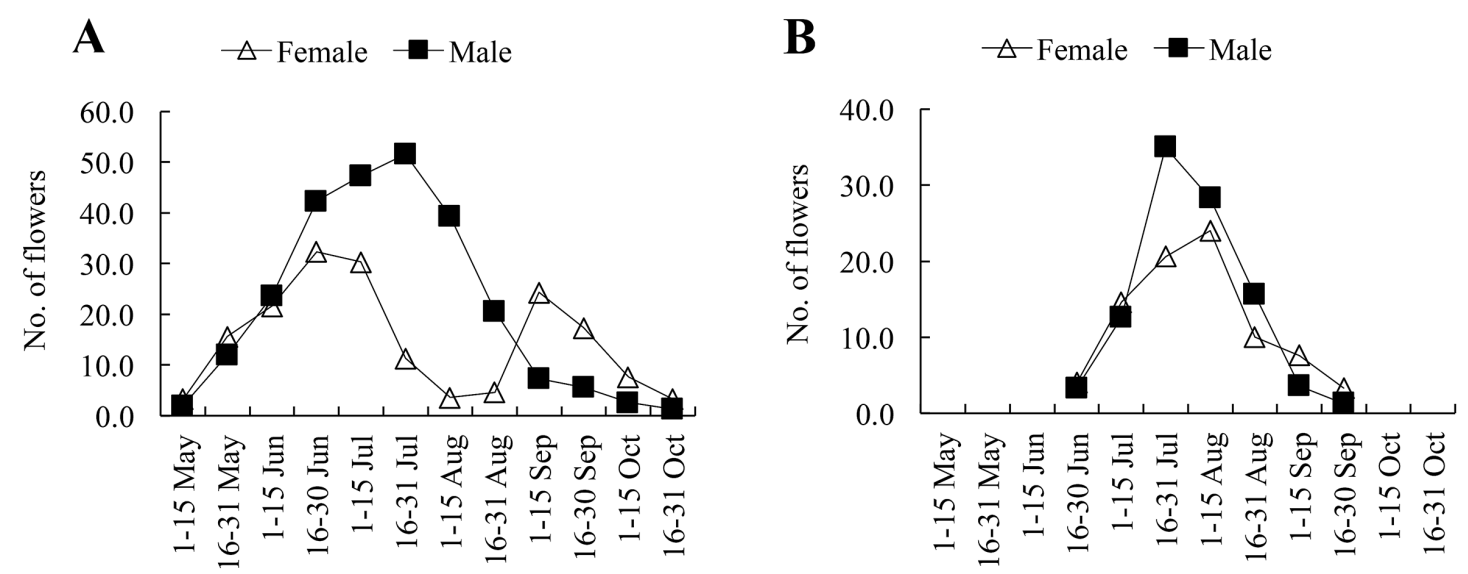

Fig. 3. Seasonal variation of flowers of pointed gourd grown in (A) glasshouse and (B) open field.

A

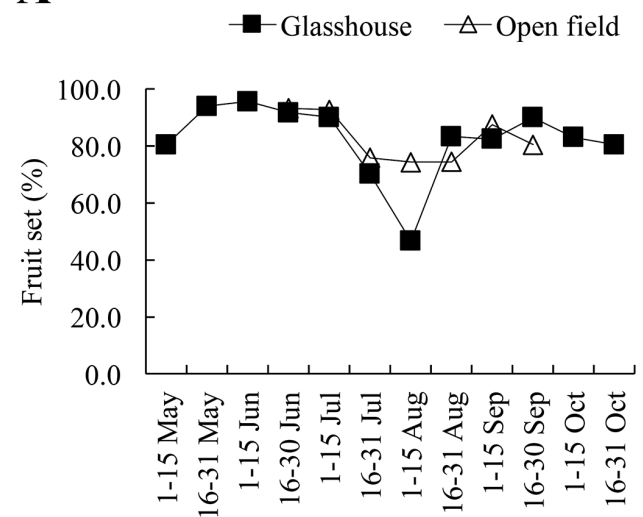

B

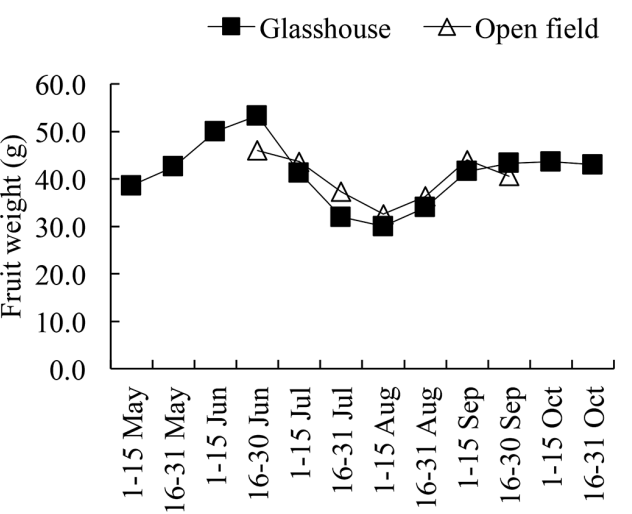

Fig. 4. Seasonal variations in fruit set rate (A), and fruit weight (g) of pointed gourd grown in glasshouse and open field.

Table 1. Seasonal variations of fruit characteristics in pointed gourd grown under glasshouse and open field condition

\begin{tabular}{|c|c|c|c|c|c|c|c|c|c|c|}
\hline \multirow{2}{*}{$\begin{array}{l}\text { Growing } \\
\text { season }\end{array}$} & \multicolumn{2}{|c|}{ No. of flower crossed } & \multicolumn{2}{|c|}{ No. of fruits obtained } & \multicolumn{2}{|c|}{ Fruit length $(\mathrm{cm})$} & \multicolumn{2}{|c|}{ Fruit diameter $(\mathrm{cm})$} & \multicolumn{2}{|c|}{ No. of seeds per fruit } \\
\hline & Glasshouse & Open field & Glasshouse & Open field & Glasshouse & Open field & Glasshouse & Open field & Glasshouse & Open field \\
\hline 1-15 May & $3.3 \pm 0.5^{z}$ & $-{ }^{y}$ & $2.6 \pm 0.5$ & - & $10.9 \pm 0.3$ & - & $3.0 \pm 0.1$ & - & $22.3 \pm 1.5$ & - \\
\hline 16-31 May & $15.6 \pm 2.0$ & - & $14.6 \pm 1.1$ & - & $11.7 \pm 0.5$ & - & $3.1 \pm 0.1$ & - & $23.6 \pm 1.5$ & - \\
\hline 1-15 Jun & $21.6 \pm 2.0$ & - & $20.6 \pm 1.1$ & - & $12.5 \pm 0.6$ & - & $3.3 \pm 0.1$ & - & $29.6 \pm 1.1$ & - \\
\hline 16-30 Jun & $32.3 \pm 2.1$ & $4.0 \pm 1.0$ & $29.6 \pm 2.3$ & $3.6 \pm 0.5$ & $13.0 \pm 0.4$ & $11.4 \pm 0.3$ & $3.5 \pm 0.1$ & $3.1 \pm 0.2$ & $31.6 \pm 1.5$ & $26.6 \pm 1.5$ \\
\hline 1-15 Jul & $30.3 \pm 2.5$ & $14.6 \pm 1.5$ & $27.3 \pm 2.0$ & $13.6 \pm 2.3$ & $11.5 \pm 0.3$ & $11.8 \pm 0.6$ & $3.2 \pm 0.1$ & $3.1 \pm 0.1$ & $24.0 \pm 1.0$ & $24.0 \pm 2.0$ \\
\hline 16-31 Jul & $11.3 \pm 1.5$ & $20.6 \pm 1.5$ & $8.0 \pm 1.7$ & $15.6 \pm 0.5$ & $9.4 \pm 0.8$ & $10.4 \pm 0.4$ & $2.9 \pm 0.1$ & $3.0 \pm 0.1$ & $20.3 \pm 1.5$ & $22.6 \pm 2.5$ \\
\hline 1-15 Aug & $3.6 \pm 1.5$ & $24.0 \pm 3.0$ & $1.6 \pm 0.5$ & $17.6 \pm 1.1$ & $8.9 \pm 0.7$ & $9.7 \pm 0.3$ & $2.6 \pm 0.1$ & $2.7 \pm 0.2$ & $17.6 \pm 1.5$ & $21.0 \pm 1.0$ \\
\hline 16-31 Aug & $4.6 \pm 1.5$ & $10.0 \pm 2.0$ & $4.0 \pm 1.7$ & $7.3 \pm 1.5$ & $9.5 \pm 0.7$ & $9.6 \pm 0.7$ & $2.8 \pm 0.2$ & $2.6 \pm 0.2$ & $20.3 \pm 1.5$ & $21.0 \pm 2.0$ \\
\hline $1-15$ Sep & $24.3 \pm 2.0$ & $7.6 \pm 0.5$ & $20.0 \pm 1.0$ & $6.6 \pm 0.5$ & $10.7 \pm 0.4$ & $12.1 \pm 0.3$ & $2.9 \pm 0.2$ & $3.2 \pm 0.1$ & $20.6 \pm 2.0$ & $26.0 \pm 2.0$ \\
\hline 16-30 Sep & $17.3 \pm 2.0$ & $3.3 \pm 0.5$ & $15.6 \pm 2.5$ & $2.6 \pm 0.5$ & $10.7 \pm 0.6$ & $10.7 \pm 0.3$ & $3.0 \pm 0.2$ & $2.9 \pm 0.1$ & $22.0 \pm 2.0$ & $23.0 \pm 2.0$ \\
\hline $1-15$ Oct & $7.6 \pm 1.1$ & - & $6.3 \pm 1.1$ & - & $11.5 \pm 0.6$ & - & $3.1 \pm 0.1$ & - & $24.3 \pm 1.5$ & - \\
\hline $16-31$ Oct & $3.3 \pm 0.5$ & - & $2.6 \pm 0.5$ & - & $10.8 \pm 0.6$ & - & $2.9 \pm 0.1$ & - & $24.6 \pm 1.5$ & - \\
\hline ANOVA $^{x}$ & $*$ & $*$ & $*$ & $*$ & $*$ & $*$ & $*$ & $*$ & $*$ & NS \\
\hline
\end{tabular}




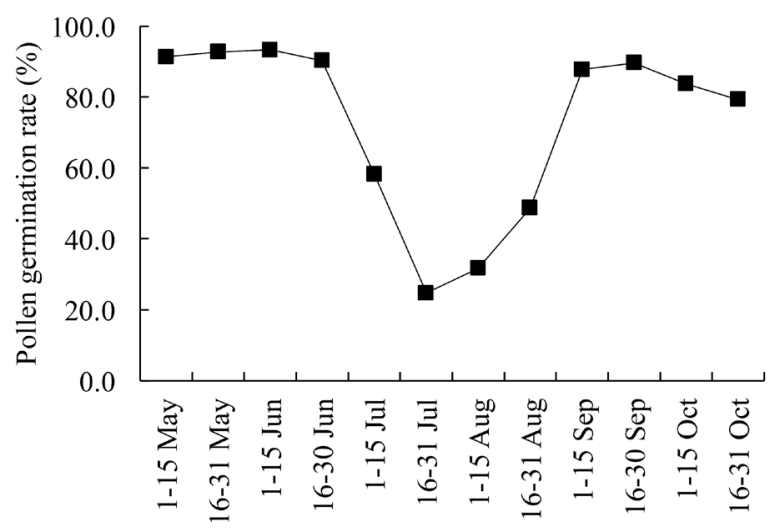

Fig. 5. Seasonal variation of pollen germination rate of male pointed gourd. Tests were performed from May to October 2017.

dency of female flowering while inhibited at $32^{\circ} \mathrm{C}$ in watermelon. Wien et al. (2004) reported that firstformed female buds at high temperature do not develop to anthesis whereas male flower production did not affect adversely in the greenhouse. Similarly, Wang (2007) concluded that males, seemed to have higher relative flowering than females at high temperature condition.

In this experiment, maximum number of fruits were obtained with increased seed and fruit weight, when flowers were pollinated in late June $\left(27.1 / 23.9^{\circ} \mathrm{C}\right)$ but decreased when they were pollinated from 16-31 July to $1-15$ August $\left(32.9-34.2^{\circ} \mathrm{C} / 28.5-29.9^{\circ} \mathrm{C}\right)$ in the glasshouse. Meanwhile, in open field, the similar pattern of result was observed in mid-July $\left(29.1 / 26.7^{\circ} \mathrm{C}\right)$ and August (29.8-30.8/27.5-27.9 $\mathrm{C})$. In particular, from 16-31 July to 16-31 August, smaller fruit with few seeds were obtained in both growing habitats. The results showed that the day/night temperature range favorable for acceptable size fruit production is between $27-29 / 23-26^{\circ} \mathrm{C}$ and temperatures above and below this range are unfavorable for it. Despite maximum male flowering in high temperature, the reduction in fruit set rate and yield suggests that pollination and fertilization might be disrupted due to high temperature conditions. Ram and Ray (1992) postulated that the optimum temperature for seed and fruit production in papaya is 27.3$29.7^{\circ} \mathrm{C}$, however, Tamaki et al. (2011) claimed it 19.4$24.6^{\circ} \mathrm{C}$ and the reason for this discrepancy might be due to cultivars differences or other cultivation factors.

It has been revealed that pollen germination ability was enhanced from 1st May to 15 July $\left(24.3-31.7^{\circ} \mathrm{C}\right)$ and 1st September to 31 October $\left(21.7-27.5^{\circ} \mathrm{C}\right)$, but reduced from 16 July to 31 August $\left(32.2-34.2^{\circ} \mathrm{C}\right)$ comparatively high temperature condition. Tamaki et al. (2011) claimed that pollen production and germination was suppressed below $15^{\circ} \mathrm{C}$ and above $30^{\circ} \mathrm{C}$, thus reduction in seed and fruit yield in papaya. Therefore, it can be assumed that fertilization failure related to the low ability of pollen germination at high temperature (more than $32^{\circ} \mathrm{C}$ ) is responsible for causing decline in fruit set and yield of pointed gourd in glasshouse during August. Hedhly et al. (2005) stated that high temperature $\left(30^{\circ} \mathrm{C}\right)$ can shorten the stigma receptivity period to pollen and decrease the chances for a successful fertilization in peach. Similarly, high temperature also causes poor anther dehiscence characterized by tight closure of the locules, which was shown to reduce pollen dispersal in tomato (Sato et al., 2002). In these aspects it has been suggested that pointed gourd pollen grains are need to be stored in a suitable condition during early growing period of abundant flowering. This stored pollen may be applicable to overcome the pollination problem appeared in this study under high temperature condition in JulyAugust.

Based on the above findings, we clarified that maximum female and male flowers of pointed gourd developed at $27.1 / 23.9^{\circ} \mathrm{C}$ (16-30 June) and $34.2 / 29.9^{\circ} \mathrm{C}(16-31$ July) in glasshouse and at $30.8 / 27.5^{\circ} \mathrm{C}$ (1-15 August) and $31.6 / 27.9^{\circ} \mathrm{C}$ (16-31 July) in open field. In addition, delayed in first flower initiation noticed in open field cultivation than that of glasshouse. But continuous flowering and fruit setting occurred in the open field while it was interrupted in the glasshouse trial during July and August growing period. Decrease in fruit set, fruit length, diameter and fruit weight regardless of growing habitats are attributed due to decline in pollen germination ability under high temperature conditions. $20-30^{\circ} \mathrm{C}$ (May-July, September-October) was found suitable for maximum pollen germination but more than $30^{\circ} \mathrm{C}$ (JulyAugust) had adverse effect on it.

\section{AUTHOR CONTRIBUTIONS}

Jahidul HASSAN, conceived the idea of the study, designed experiment, performed the research and data analysis, and wrote the manuscript. Ikuo MIYAJIMA, supervised the work, provided suggestions and comments on the manuscript. All authors assisted in editing the manuscript and approved the final version.

\section{REFERENCES}

Allan, P. 1963 Pollen studies in Carica papaya. I. Formation, development, morphology and production of pollen. S. Afr. J. Agric. Sci., 6: $517-530$

Bangladesh Climate Data Portal (BCDP) 2015 Climates to travel, world climate guide. https://www.climatestotravel.com/climate/ bangladesh

Cantliffe, D. J. 1981 Alteration of sex expression in cucumber due to changes in temperature, light intensity and photoperiod. $J$. Am. Soc. Hort. Sci., 106: 133-136

Frick, B. and P. B. Cavers 1989 Aberrations in sex expression in Silene latifolia. Am. Nat., 134: 562-573

Hedhly, A., J. I. Hormaza and M. Herrero 2005 The effect of temperature on pollen germination, pollen tube growth and stigmatic receptivity in peach. Plant Biology, 7: 476-483

Koley, T. K., R. Asrey and D. V. K. Samuel 2009 Effect of sanitizers and storage environment on shelf-life and quality of pointed gourd (Trichosanthes dioica). Indian J. Agr. Sci., 79: 170-173

Kumar, S. and B. D. Singh 2012 Pointed Gourd: Botany and Horticulture. Horticultural Reviews, 39: 203-238

Leus, L. 2005 Resistance breeding for powedery mildew (Podosphaera pannosa) and black spot (Diplocarpon rosae) in 
roses. PhD Thesis, Faculty of Bioscience Engineering, Ghent University, Belgium

Peter, K. V., M. K. Sadhu, M. Raj and K. P. Prasnna 1998 Improvement and cultivation: Bitter gourd, snake gourd, pointed gourd and ivy gourd. In "Cucurbits", ed. By N.M. Nayar and T.A. More, Oxford and IBH Publ., New Delhi, India, pp.187-198

Ram, M. and P. K. Ray 1992 Influence of fruiting season on seed production of papaya under North Bihar. Seed Research, 20: $81-84$

Rudich, J. and A. Peles 1976. Sex expression in watermelon as affected by photoperiod and temperature. Sci. HorticAmsterdam, 5: 339-344

Sato, S., M. M. Peet and J. F. Thomas 2002 Determining critical pre- and post-anthesis periods and physiological process in Lycopersicon esculentum Mill. Exposed to moderately elevated temperatures. Journal of Experimental Botany, 53: 1187-1195

Song, S., H. Huang, H. Liu, G. Sun and R. Chen 2012 Low temperature during seedling stage promotes female flower determination but not yield of Chieh-qua. Hort. Environ. Biotechnol., 53(5): 343-348

Tamaki, M., N. Urasaki, Y. Sunakawa., K. Motomura and S. Adaniya 2011 Seasonal variations in pollen germination ability, reproductive function of pistils, and seeds and fruit yield in papaya
(Carica papaya L.) in Okinawa. J. Japan. Soc. Hort. Sci., 80(2): 156-163

Taylor, D. R. 1994 The genetic basis of sex ratio in Silene alba (=S. latifolia). Genetics, 136: 641-651

Terefe, D. and T. Tatlioglu 2005 Isolation of a partial sequence of a putative nucleotide sugar epimerase, which may involve in stamen development in cucumber (Cucumis sativus L.). Theor. Appl. Genet., 111: 1300-1307

Wang, X. 2007 Gender-specific flowering responses to day length in the dioecious plant Silene latifolia at different temperatures. Sex Plant Reprod., 20: 45-50

Wein, H. C., S. C. Stapleton, D. N. Maynard, C. McClurg and D. Riggs 2004 Flowering, sex expression, and fruiting of pumpkin (Cucurbita sp.) cultivars under various temperatures in greenhouse and distant field trials. HortScience, 39(2): 239-242

Yamasaki, S., N. Fujii and H. Takahashi 2005 Hormonal regulation of sex expression in plants. Vitam. Horm, . 72: 79-110

Young, L. W., R. W. Wilen and P. C. Bonham-Smith 2004 High temperature stress of Brassica napus during flowering reduces micro- and megagametophyte fertility, induces fruit abortion, and disrupts seed production. Journal of Experimental Botany, $\mathbf{5 5}$ : 485-495 